\title{
Flow Cytometric Determination of Cell Cycle Parameters of V79 Cells by Continuous Labeling with Bromodeoxyuridine
}

\author{
Kohzaburo Fujikawa-Yamamoto, Nariko Miyashita* and Shizuo \\ Odashima*
}

Central Research Laboratory, *Department of Pathology, Kanazawa Medical University, Uchinada, Ishikawa 920-02, Japan

\begin{abstract}
A simple method with which to determine the cell cycle parameters, $T_{\mathrm{G} 1}, T_{\mathrm{S}}$ and $\mathrm{T}_{\mathrm{G} 2 \mathrm{M}}$ (the durations of the $\mathrm{G}_{1}, \mathrm{~S}$ and $\mathrm{G}_{2}+\mathrm{M}$ phases) is described. V79 Chinese hamster lung cells were used to evaluate the method. After continuous labeling with bromodeoxyuridine (BrdU), V79 cells were stained with anti BrdU-monoclonal antibody with FITC (fluorescein isothiocyanate) and with PI (propidium iodide). The individual cells were checked by flow cytometry for green and red fluorescences whose signal intensities corresponded to the BrdU and cellular DNA contents. The durations of $\mathrm{G}_{1}$, $\mathrm{S}$ and $\mathrm{G}_{2}+\mathrm{M}$ phases of V79 cells were determined by measuring the cell fractions containing the nonlabeled $G_{1}$, labeled $S$ and nonlabeled $G_{2}+M$ phases. The reliability of this method is discussed.
\end{abstract}

Many methods have been developed to determine the cell cycle parameters, $\mathrm{T}_{\mathrm{G} 1}$, $T_{\mathrm{S}}$ and $\mathrm{T}_{\mathrm{G} 2 \mathrm{M}}$ (the durations of the $\mathrm{G}_{1}, \mathrm{~S}$ and $\mathrm{G}_{2}+\mathrm{M}$ phases) in a cell population growing exponentially $(2,7,15,21,22,25,27,28)$. In the cell cycle analysis method, the values of these cell cycle parameters in a cell population apparently are not affected by the measurement probes used.

Flow cytometry (20) has proven a reliable technique for the rapid measurement of kinetic parameters in a large cell population with minor perturbation to the cells (29). The simplest flow cytometric method for cell cycle analysis may be the method by which the $T_{G 1}$, $T_{S}$ and $T_{G 2 M}$ values in a cell population growing exponentially are determined from the ratio of cell fraction at each phase and from the duration of one cell cycle, $T_{c},(16)$. In this method, however, the fraction at each phase tends to vary with the analytical method used in the DNA fluorescence histogram analysis, and progression of the cell cycle can not be checked directly.

An autoradiography technique that uses the uptake of $\left[{ }^{3} \mathrm{H}\right]$-thymidine has been extensively favored to determine the duration of each cell phase, and it has little effect on the cell cycle. The labeled mitosis method, in which the duration of each phase is determined from periodic changes in the labeled mitosis fractions after pulse labeling with $\left[{ }^{3} \mathrm{H}\right]$-thymidine, also is often used. The $\mathrm{RCS}_{\mathrm{i}}$ method (radioactivity per cell in a narrow window, $S_{i}$, in $S$ phase) of cell cycle analysis was developed by Gray et al. (15) and is a combination of flow cytometry and autoradiography. But, although autoradiography is useful and reliable, more than a week is required to obtain results.

Recently, an anti-bromodeoxyuridine monoclonal antibody has been developed 
(14) and used in flow cytometry $(5,6)$. In this technique, cells are doubly stained, with FITC for BrdU and with PI for DNA. When the stained cells are irradiated by a laser at $488 \mathrm{~nm}$ (the excitation light), the relative intensity of the green and red fluorescence present in the individual cells corresponds to their cellular BrdU and DNA contents. With this method, differential counting of BrdU-labeled cells, nonlabeled $G_{1}$ cells and nonlabeled $G_{2}+M$ phase cells can be done satisfactorily (13).

We here introduce a method to determine the cell cycle parameters in a cell population growing exponentially. V79 cells were used to check the method because of their short cell cycle. Changes in the fractions of the nonlabeled $\mathrm{G}_{1}$ and nonlabeled $\mathrm{G}_{2}+\mathrm{M}$ phase cells in a V79 cell population labeled continuously with BrdU were measured, and the duration of each phase in the cell cycle was determined. By this method, the $T_{G 1}$ and $T_{G 2 M}$ values could be determined accurately, whereas the value of $T_{S}$ varied; therefore, a simulation method was used to determine the $T_{S}$ value.

\section{MATERIALS AND METHODS}

Cells. V79 Chinese hamster lung cells (line V79-B, obtained from Dr. Ishii, Osaka University) $(11,23)$ were maintained in a humidified atmosphere of $10 \% \mathrm{CO}_{2}$ at $37^{\circ} \mathrm{C}$ as growing monolayer cultures in Dulbecco-Vogt modified Eagle's medium containing 9\% fetal bovine serum (FBS, HyClone, Sterile Systems Inc.). The culture was routinely subcultured at low density twice a week by splitting it at a ratio of about $1: 50$.

Cell preparation. V79 cells in logarithmic growth were plated in petri dishes $(90 \phi$; Falcon Plastics) at a density of $1 \times 10^{4}$ cells per dish. BrdU (Sigma) then was added at a final concentration of $10 \mu \mathrm{M}$ at time $\mathrm{t}=0$, and the dishes cultured in a $\mathrm{CO}_{2}$ incubator. At various intervals (Fig. 4) cells were washed with PBS $^{(-)}$(divalent cation-free phosphatebuffered saline) then treated with $0.3 \mathrm{ml}$ trypsin-EDTA $(0.02 \%$ and $0.2 \mathrm{mM})$ for $5 \mathrm{~min}$ at room temperature (RT), after which they were suspended in $5 \mathrm{ml}$ of medium containing $9 \%$ FBS. This suspension was centrifuged and the cells resuspended in $\mathbf{P B S}^{(-)}$. After being left for $30 \mathrm{~min}$ at $0^{\circ} \mathrm{C}$, the cells were fixed with $40 \%$ ethanol at $0^{\circ} \mathrm{C}$ for $1 \mathrm{~h}$ then stored at $4^{\circ} \mathrm{C}$ until use.

Cell staining. The fixed V79 cells were suspended in PBS $\left.{ }^{-}\right)$containing $0.25 \%$ RNase (Type II-A, Sigma) then incubated for $30 \mathrm{~min}$ at $37^{\circ} \mathrm{C}$, after which they were treated with $2 \mathrm{~N} \mathrm{HCl}$ for $45 \mathrm{~min}$ at $25^{\circ} \mathrm{C}$ then neutralized with $0.1 \mathrm{M} \mathrm{Na}_{2} \mathrm{~B}_{4} \mathrm{O}_{7}(\mathrm{pH} 8.5$ ). Treatment with $\mathrm{HCl}$ denatures the double strand of the DNA producing single strand DNA, thus permitting the reaction of the anti BrdU monoclonal antibody to BrdU to take place in the DNA chain. In this experiment, the length of $\mathrm{HCl}$ treatment was made relatively long in order to detect, as accurately as possible, the incorporated BrdU molecules. About $10^{6}$ cells were suspended in $50 \mu \mathrm{l} \mathrm{PBS}{ }^{(-)}$containing $0.5 \%$ Tween $20,2 \%$ BSA (bovine serum albumin) and $1 \mu \mathrm{l}$ antiBrdU monoclonal antibody (Becton Dickinson) then incubated for $1 \mathrm{~h}$ at RT. After these cells had been washed 3 times with PBS $^{(-)}$, they were stained with FITC-conjugated goat anti mouse IgG (Miles-Yeda Ltd.) to BrdU for $1 \mathrm{~h}$ at RT.

The stained cells were washed twice with $\mathrm{PBS}^{(-)}$then stained with PI solution $(50 \mu \mathrm{g}$ $\mathrm{PI} / 1 \mathrm{ml} \mathrm{PBS}(-))$ to determine the total DNA present. The doubly stained cells were checked in a flow cytometer for their green and red fluorescence as described below.

Flow cytometric measurements. The green and red fluorescence of individual V79 cells was measured with a Cytofluorograf system $50 \mathrm{H}$ (Ortho Instruments) equipped with a $5 \mathrm{~W}$ argon ion laser. The fluorescence from individual cells irradiated with a focused laser beam at $488 \mathrm{~nm}$ ( $200 \mathrm{~mW}$ laser power) as the excitation light was separated optically through an 
interference filter $(530 \mathrm{~nm}$ peak and $20 \mathrm{~nm}$ band width) and a cut off filter (50\% transmittance at $635 \mathrm{~nm}$ ) and detected by photomultiplier tubes. The differential counting of the $\mathrm{G}_{1}$, $\mathrm{S}$ and $\mathrm{G}_{2}+\mathrm{M}$ phase cells in a cell population was done visually through electronic windows for green and red fluorescence. The fractions of the $G_{1}, S$ and $G_{2}+M$ phase cells were determined directly by counting the signals through the respective windows.

\section{RESULTS}

(A) Analytical equations. Cells in an asynchronous cell population are believed to traverse the cell cycle at a constant rate; i.e., the cell number increases exponentially with the time, $\mathrm{t}$. Therefore, let $\mathrm{n}(\mathrm{t}, \tau)$ be the number of cells per unit time at time $\mathrm{t}$ following through a point in the cell cycle which precedes division by time $\tau$. $\mathrm{n}(\mathrm{t}, \tau)$ can be written $(25,22)$

$$
\begin{aligned}
\mathrm{n}(\mathrm{t}, \tau) & =\alpha \mathrm{N}_{0} \exp (\alpha \mathrm{t}) \exp (\alpha \tau), \\
\alpha & =\ln 2 / \mathrm{T}_{\mathrm{c}}
\end{aligned}
$$

in which $N_{0}$ is the initial number of cells in mitosis and $T_{c}$ is the length of the cell cycle.

If it is assumed that $\mathrm{S}$ phase cells incorporate BrdU as soon as it is added and that the progression of the cell cycle is not affected by its presence, the fractions representing the BrdU-labeled cells $\left(F_{1}\right)$, nonlabeled $G_{1}$ cells $\left(F_{G_{1}}\right)$ and nonlabeled $G_{2}+M$ cells $\left(F_{G_{2} M}\right)$ theoretically can be derived as functions of time t using Eqs. (1) and (2), as shown in Table 1. In Table 1, approximated equations also are given to facilitate the analysis. In practice, cell cycle parameters were determined using these approximate equations.

(B) Analysis of the cell cycle of V79 cells. To determine the cell cycle parameters, $\mathrm{T}_{\mathrm{G} 1}, \mathrm{~T}_{\mathrm{S}}$ and $\mathrm{T}_{\mathrm{G} 2 \mathrm{M}}, \mathrm{V} 79$ cells were labeled continuously with BrdU, then stained with PI for cellular DNA and with FITC for BrdU, after which the individual green and red fluoretcences were measured by flow cytometry. At various times, the fractions containing BrdU-labeled cells, $F_{1}(t)$, nonlabeled $G_{1}$ phase cells, $F_{G 1}(t)$ and nonlabeled $\mathrm{G}_{2}+\mathrm{M}$ phase cells, $\mathrm{F}_{\mathrm{G} 2 \mathrm{M}}(\mathrm{t})$ were measured.

\begin{tabular}{|c|c|c|c|}
\hline & \multirow{2}{*}{ Theoretical expression } & \multicolumn{2}{|c|}{ Approximate expression $F(t)=a t+b$} \\
\hline & & a & $\mathrm{b}$ \\
\hline \multicolumn{4}{|c|}{$\mathrm{F}_{1}(\mathrm{t})$} \\
\hline$t_{1}$ & $-\exp \left\{\alpha\left(\mathrm{T}_{\mathrm{G} 2 \mathrm{M}}-\mathrm{t}\right)\right\}+2 \exp \left(-\alpha \mathrm{T}_{\mathrm{G} 1}\right)$ & $\left\{\exp \left(\alpha \mathrm{T}_{\mathrm{G} 2 \mathrm{M}}\right)-1\right\} / \mathrm{T}_{\mathrm{G} 2 \mathrm{M}}$ & $2 \exp \left(-\alpha \mathrm{T}_{\mathrm{G} 1}\right)-\exp \left(\alpha \mathrm{T}_{\mathrm{G} 2 \mathrm{M}}\right)$ \\
\hline$t_{2}$ & $-2 \exp \left\{a\left(T_{G 2 M}-t\right)\right\}+1+2 \exp \left(-\alpha T_{G 1}\right)$ & $\left\{2-2 \exp \left(-\alpha \mathbf{T}_{\mathrm{G} 1}\right)\right\} / \mathbf{T}_{\mathrm{G} 1}$ & $1-\left\{2-2 \exp \left(-\alpha \mathrm{T}_{\mathrm{G} 1}\right)\right\}\left(\mathrm{T}_{\mathrm{G} 2 \mathrm{M}}+\mathrm{T}_{\mathrm{G} 1}\right) / \mathbf{T}_{\mathrm{G} 1}$ \\
\hline \multicolumn{4}{|c|}{$\mathrm{F}_{\mathrm{G} 1}(\mathrm{t})$} \\
\hline$t_{1}$ & $2-2 \exp \left(-\alpha T_{G 1}\right)$ & 0 & $2-2 \exp \left(-\alpha \mathrm{T}_{\mathrm{G} 1}\right)$ \\
\hline$t_{2}$ & $2 \exp \left\{a\left(\mathrm{~T}_{\mathrm{G} 2 \mathrm{M}}-\mathrm{t}\right)\right\}-2 \exp \left(-\alpha \mathrm{T}_{\mathrm{G} 1}\right)$ & $-\left\{2-2 \exp \left(-a \mathrm{~T}_{\mathrm{G} 1}\right)\right\} / \mathrm{T}_{\mathrm{G} 1}$ & $\left\{2-2 \exp \left(-\alpha \mathrm{T}_{\mathrm{G} 1}\right)\right\}\left(\mathrm{T}_{\mathrm{G} 2 \mathrm{M}}+\mathrm{T}_{\mathrm{G} 1}\right) / \mathrm{T}_{\mathrm{G} 1}$ \\
\hline \multicolumn{4}{|c|}{$F_{G 2 M}(t)$} \\
\hline$t_{1}$ & $\exp \left\{\alpha\left(\mathrm{T}_{\mathrm{G} 2 \mathrm{M}}-\mathrm{t}\right)\right\}-1$ & $-\left\{\exp \left(\alpha \mathrm{T}_{\mathrm{G} 2 \mathrm{M}}\right)-1\right\} / \mathrm{T}_{\mathrm{G} 2 \mathrm{M}}$ & $\exp \left(\alpha \mathrm{T}_{\mathrm{G} 2 \mathrm{M}}\right)-1$ \\
\hline
\end{tabular}

TABLE 1. TheORETICAL eXPRESSION OF $F_{1}(t), F_{G 1}(t)$ AND $F_{G 2 M}(t)$

$F_{1}(t), F_{G_{1}}(t)$ and $F_{G_{2} M}(t)$ are the fractions of BrdU-labeled cells, nonlabeled $G_{1}$ cells and nonlabeled $\mathrm{G}_{2}+\mathrm{M}$ cells at time $t$. $T_{\mathrm{G} 1}, T_{\mathrm{S}}$ and $T_{\mathrm{G} 2 \mathrm{M}}$ are the durations of the $\mathrm{G}_{1}, \mathrm{~S}$ and $\mathrm{G}_{2}+\mathrm{M}$ phases. $a$ equals $\ln 2 / T_{c}$ and $T_{c}=T_{G 1}+T_{S}+T_{G 2 M} \cdot t_{1}$ and $t_{2}$ are the times when $0 \leqq t_{1} \leqq T_{G_{2} M}$ and $T_{G_{2} M} \leqq t_{2} \leqq T_{G 2 M}+T_{G 1}$. 
A cytogram (upper panel) of the green fluorescence relative intensity $\left(F_{530}\right)$-red fluorescence relative intensity $\left(F_{>600}\right) 10$ min after the BrdU addition and its schematic pattern (lower panel) are shown in Fig. 1. Each dot represents a cell. In the upper panel, the lower left population is that of the $G_{1}$ phase cells, the lower right that of the $G_{2}+M$ phase cells and the other that of the $S$ phase cells. In the lower panel, the three rectangles with the symbols $G_{1}, S$ and $G_{2}+M$ represent the counting windows for nonlabeled $G_{1}$ cells, labeled cells and nonlabeled $G_{2}+M$ cells. Another window, $\mathrm{T}$, which included all three windows was set for counting the total number of cells. These windows were set visually. The cell fractions passing through the $G_{1}, S$ and $\mathrm{G}_{2}+\mathrm{M}$ windows were determined from the ratio of the cell number shown in each window to the number shown in the $\mathrm{T}$ window.

The change in the cytograms after the addition of BrdU is shown in Fig. 2. Careful inspection of this figure shows that the nonlabeled $G_{2}+M$ and $G_{1}$ phase cells dis-

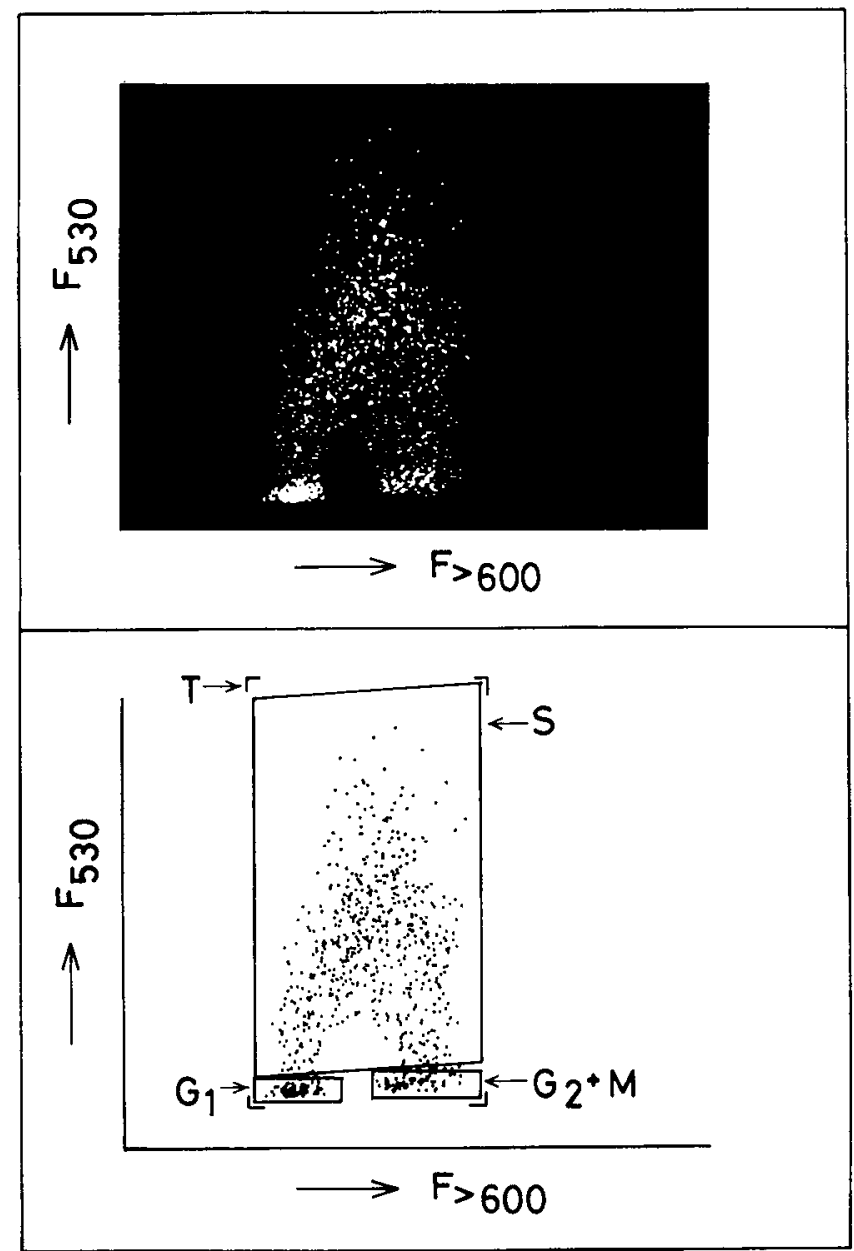

Fig. 1. $F_{530}-F_{>600}$ cytogram (A) and the schematic pattern (B). Rectangles labeled with $\mathrm{G}_{1}$, $S$ and $G_{2}+M$ represent the differential counting windows for the $G_{1}, S$ and $G_{2}+M$ phase cells. The four angles represent the corners of the $T$ window used to count the total cell number. 

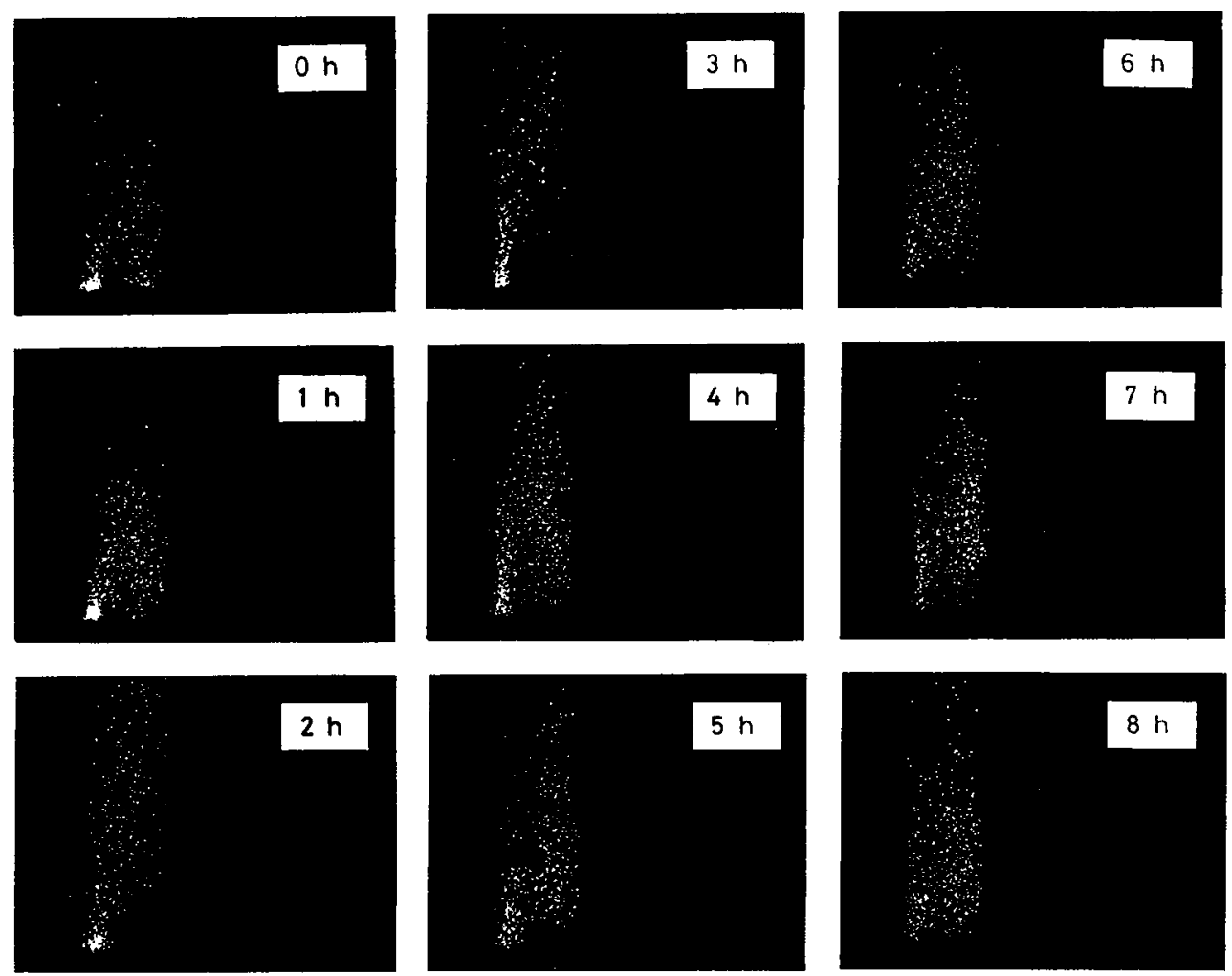

Fig. 2. Changes in $F_{530}-F_{>600}$ cytograms with time after a BrdU addition. Numerals in each cytogram represent the incubation time (h) after the BrdU addition.

appear at $3 \mathrm{~h}$ and $6 \mathrm{~h}$ after the addition.

The affect of BrdU on the progression of V79 cells through the cell cycle was examined by measuring the changes in the DNA fluorescence histogram patterns after the BrdU addition. Red fluorescence histograms at $0,0.5$ and $12 \mathrm{~h}$ after the addition are shown in Fig. 3. These histograms were assayed for the $G_{1}, S$ and $G_{2}+M$ phase fractions by cell cycle analysis $(12,13)$. Although no marked changes in these fractions were observed, a slight difference was found in the DNA distribution in the $S$ phase. The late $S$ phase fraction becomes low on the histogram $12 \mathrm{~h}$ after the BrdU addition. Note that the histograms in Fig. 3 are normalized for peak height.

Changes with time after BrdU addition in the fractions of labeled cells, nonlabeled $G_{1}$ cells, nonlabeled $G_{2}+M$ cells and the total cells were counted through the respective windows shown in Fig. 1. Changes in the experimental values of $F_{1}(t), F_{G 1}(t)$ and $F_{G 2 M}(t)$ are shown in Fig. 4. $T_{G 1}$ and $T_{G 2 M}$ values were determined accurately with an error of less than $30 \mathrm{~min}$, from the times when $F_{G_{1}}(t)$ and $G_{G_{2} M}(t)$ became zero. Because the $T_{\mathrm{s}}$ value, in contrast, must be determined from the slope and/or the cell fraction at $t=0$, it was taken from simulation curves in which the $T_{0}$ values were varied and the $T_{G 1}$ and $T_{G 2 M}$ values fixed as described. Solid lines (A), (B) and $(C)$ represent the simulation curves of $T_{c}=11,13$ and $15 h$ when $T_{G 1}=3.4$ and $T_{\mathrm{G} 2 \mathrm{M}}=2.4 \mathrm{~h}$. The duration of $\mathrm{T}_{\mathrm{G} 1}, \mathrm{~T}_{\mathrm{S}}$ and $\mathrm{T}_{\mathrm{G} 2 \mathrm{M}}$ were determined as $3.4 \pm 0.5,7.2 \pm 2.0$ and $2.4 \pm 0.5 \mathrm{~h}$. 


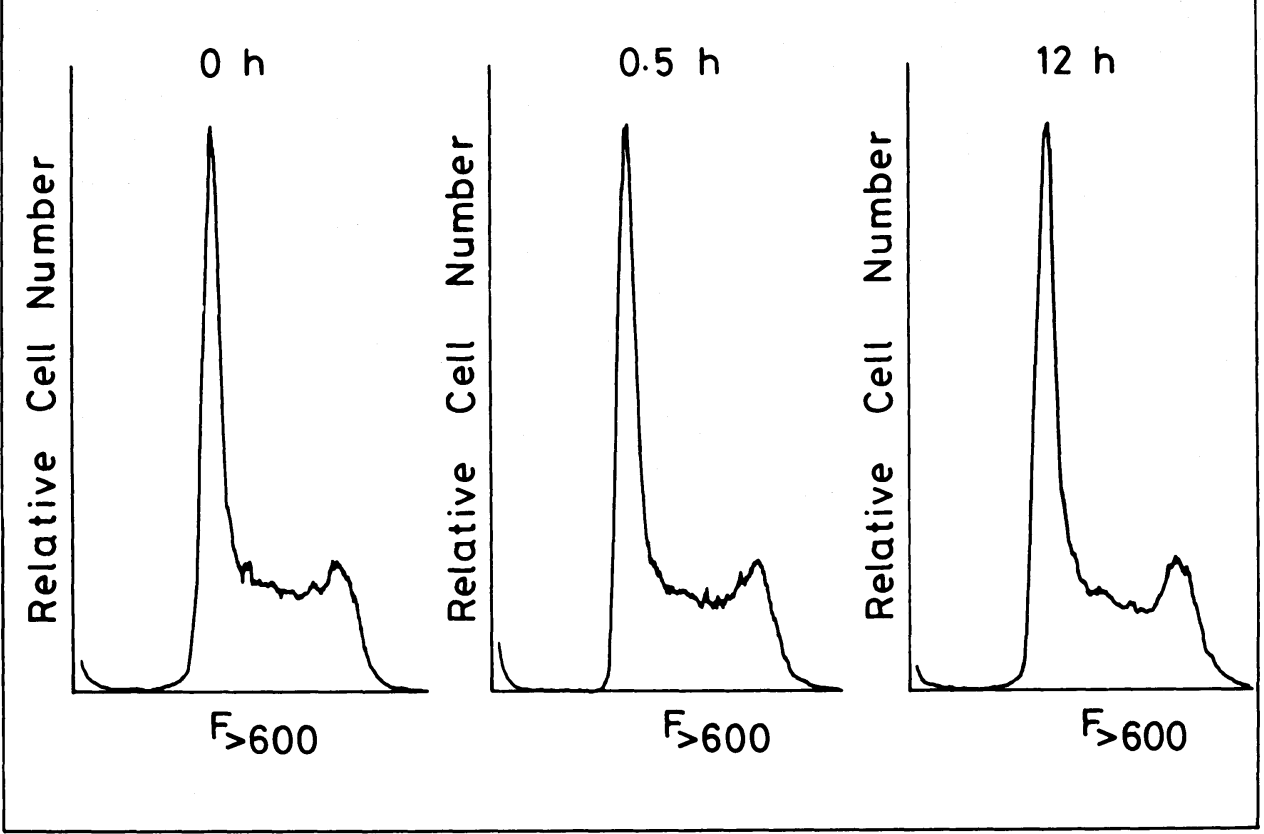

Fig. 3. Changes in $F_{>600}$ frequency distribution histograms with time after a BrdU addition. The numerals in each histogram gives the incubation time in hours after the BrdU addition.

\section{DISCUSSION}

There are many methods to determine the cell cycle parameters $T_{\mathrm{G} 1}, \mathrm{~T}_{\mathrm{S}}$ and $\mathrm{T}_{\mathrm{G} 2 \mathrm{M}}$, for a cell population in balanced growth. The best method requires high accuracy for the values obtained, a short determination period and the reliability that the method itself will not alter the cell cycle parameter values.

DNA histogram analysis of flow cytometry is useful for determining the $G_{1}, S$ and $\mathrm{G}_{2}+\mathrm{M}$ phase fractions in a cell population in balanced growth $(1,3,4,8,9,10,12$, $13,19,26)$. But, fractions obtained by cell cycle analysis may be somewhat inaccurate depending on the treatment of the $G_{1}-S$ and $S-G_{2}$ boundaries. In addition, the $T_{c}$ value must be known in order to calculate $T_{G 1}, T_{S}$ and $T_{G 2 M}$ from the fractions obtained.

The BrdU continuous labeling method described in this report has several advantages: The length of the measurement period is relatively short; only the length of $\mathrm{T}_{\mathrm{G} 1}+\mathrm{T}_{\mathrm{G} 2 \mathrm{M}}$ (or $\mathrm{T}_{\mathrm{G} 2 \mathrm{M}}$ ) is required to determine all the cell cycle parameters. In addition, the $G_{1}, S$ and $G_{2}+M$ phase fractions can be accurately determined from the sample at $t=0$. Also, progression of the cell cycle can be observed directly.

Although the values of $T_{G 1}$ and $T_{G 2 M}$ were easily determined from the time when $F_{G 1}(t)$ and $F_{G 2 M}(t)$ became zero, the $T_{S}$ value had to be determined from simulation curves. The simulation method was used for two practical reasons; a small variation in the phase fraction was enlarged on the $T_{\mathrm{S}}$ value and the degree of the slope was correlated with the phase fractions.

The simulation curves were approximated by using the first order functions of $t$. Approximation curves (solid lines) and exact ones (dotted lines) are shown in Fig. 5. 


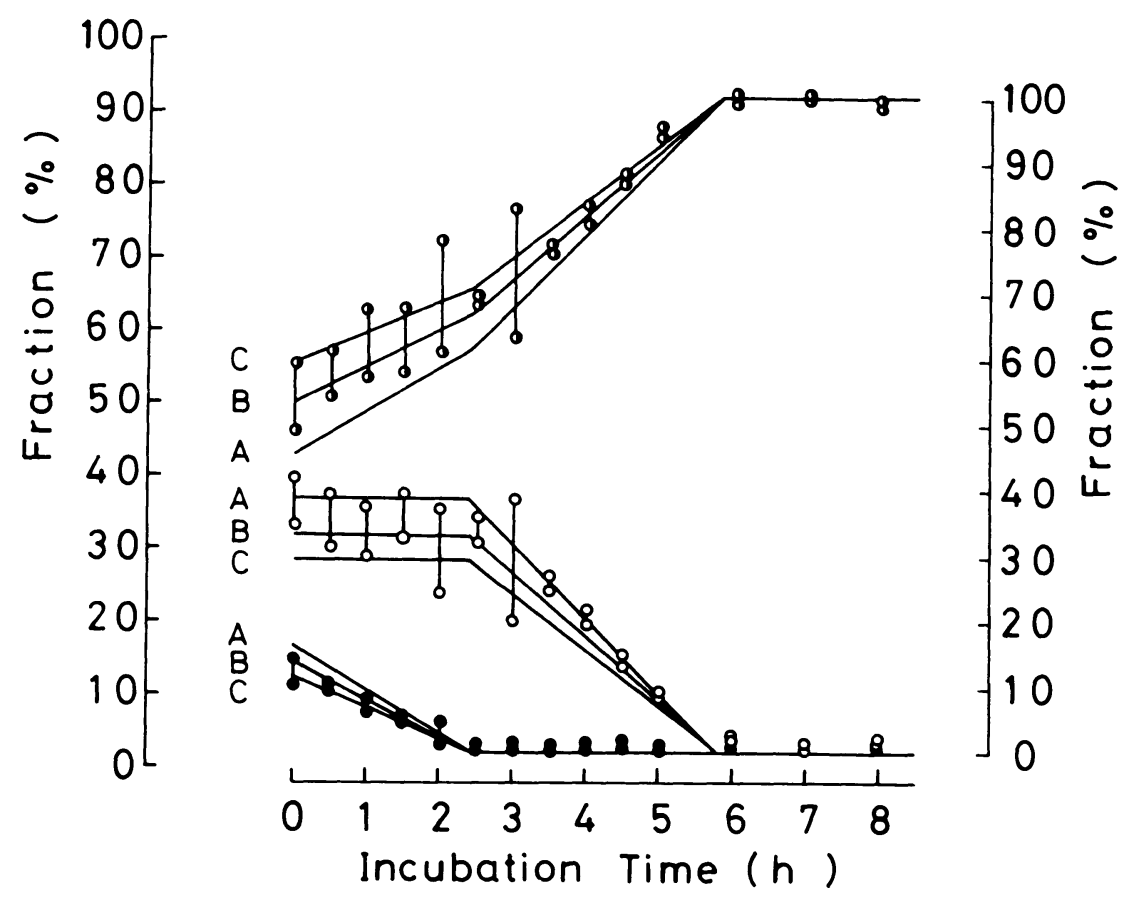

Fig. 4. Changes in the fractions of labeled cells $(\mathbf{O})$, nonlabeled $\mathbf{G}_{1}$ cells $(\bigcirc)$ and nonlabeled $\mathrm{G}_{2}+\mathrm{M}$ cells $(\bullet)$ with incubation time after a BrdU addition. The abscissa gives the incubation time in hours. The left ordinate shows fractions actually observed. The right ordinate shows cell fractions corrected by considering noncycling cells. The solid lines (A), (B) and (C) are the simulation curves of $T_{c}=11,13$ and $15 \mathrm{~h}$, when $T_{G 1}$ and $T_{G 2 M}$ were fixed as 2.4 and $3.4 \mathrm{~h}$. Each circle represents the mean of ten measurements. Duplicate measurements were made, the results at particular times being combined with the longitudinal bar.

It is clear that any differences between the approximate and exact curves fall within the experimental error of measurement.

It is necessary to discuss the affect of BrdU on the progression of the cell cycle because $\mathrm{BrdU}$ is known to interfere with the advancement of some cycles $(17,18,24)$. Fortunately, there was no marked effect of BrdU on the growth rate and cell phase fractions of the V79 cell population used. Recently we observed that B16 melanoma cells growing in MEM (minimal essential medium) supplemented with $2 \%$ FBS were affected by BrdU in concentrations above $0.5 \mu \mathrm{M}$ (unpublished data). The effect of BrdU may vary with the growth conditions (e.g. the concentration of serum) and with the characteristics of the cells such as the amount of endogenous thymidine in the cells, the activities of kinases and deaminases and the functioning of alternate synthetic pathways. Serious effects of BrdU on a cell cycle would exclude use of any method in which cell cycle parameter values are determined from the cell cycle progression of BrdU-labeled cells, as is the case with the $\mathrm{RCS}_{\mathrm{i}}$ method (15).

Nonlabeled cells disappeared in the cytograms at 6,7 and $8 \mathrm{~h}$ (Fig. 2), which means that all the cells in the cell population advanced in the cycle and took up $\mathrm{BrdU}$ in the $\mathrm{S}$ phase. There is a possibility that cells containing BrdU change their cell cycle character after the BrdU uptake. It will be sure that BrdU is incorporated in 


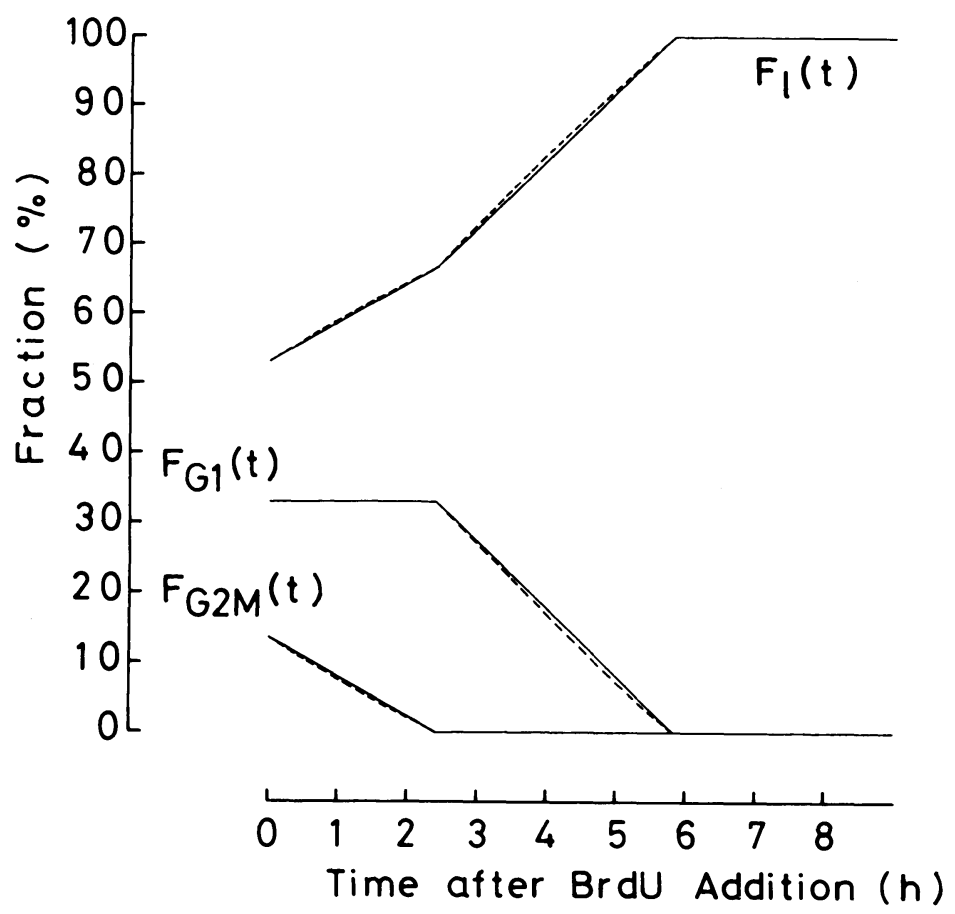

Fig. 5. Theoretical (broken lines) and approximate (solid lines) curves of $F_{1}(t), F_{G 1}(t)$ and $F_{G 2 M}(t) . T_{G 1}, T_{S}$ and $T_{G 2 M}$ values were fixed to $3.4,7.2$, and $2.4 \mathrm{~h}$.

S phase to DNA and that nonlabeled cells advance normally in the cycle. In our continuous BrdU-labeling method, therefore, the results are not affected by the presence of BrdU because the values of cell cycle parameters are determined by the times when the nonlabeled $G_{1}$ and $G_{2}+M$ phase cell fractions disappear and by the fractions of the $G_{1}, S$ and $G_{2}+M$ phase cells at time, $t=0$.

Acknowledgements. We thank Dr. Masao Inoue, for his generous encouragement during our study. This research was supported in part by a grant from the Science Research Promotion Fund (1985) of the Japan Private School Promotion Foundation.

\section{REFERENCES}

1. Baisch, H., W. Gohde and W. A. Linden. Analysis of PCP-data to determine the fraction of cells in the various phases of cell cycle. Radiat. Environ. Biophys. 12, 31-39, 1975

2. BoHmER, R.M. Flow cytometric cell cycle analysis using the quenching of 33258 Hoechst fluorescence by bromodeoxyuridine incorporation. Cell Tissue Kinet. 12, 101-110, 1979

3. Dean, P.N. and J.H. JetT. Mathematical analysis of DNA distributions derived from flow microfluorometry. J. Cell Biol. 60, 523-527, 1974

4. Dean, P.N. A simplified method of DNA distribution analysis. Cell Tissue Kinet. 13, 299-309, 1980

5. Dolbeare, F., H. Gratzner, M.G. Pallavicini, A. Russo and J.B. Mitchell. Bromodeoxyuridine in tumors and chromosomes detected with a monoclonal antibody. J. Clin. Invest. 72, 1844-1850, 1983 
6. Dolbeare, F., H. Gratzner, M.G. Pallavicini and J.W. Gray. Flow cytometric measurement of total DNA content and incorporated bromodeoxyuridine. Proc. Natl. Acad. Sci. USA. 80, 5573-5577, 1983

7. Edwards, J.L., A.L. Koch, P. Youcis, H.L. Freese, M.B. Laite and J.H. Donalson. Some characteristics of DNA synthesis and the mitotic cycle in Ehrlich ascites tumor cells. Biophys. Biochem. Cytol. 7, 273-281, 1960

8. Eisen, M. and J. Schiller. Microfluorometry analysis. T. Theoret. Biol. 66, 799-809, 1977

9. Fried, J., X. Yataganas, T. Kitahara, A. Perez, R. Furguson, S. Sullivan and B. Clarkson. Quantitative analysis of flow microfluorometric data from asynchronous and drugtreated cell populations. Comput. Biomet. Res. 9, 277-290, 1976

10. FRIED, J. Analysis of deoxyribonucleic acid histograms from flow cytofluorometry, estimation of the distribution of cells within S phase. J. Histochem. Cytochem. 25, 942-951, 1977

11. Fujikawa-Yamamoto, K. RNA dependence in the cell cycle of V79 cells. J. Cell. Physiol. 112, 60-66, 1982

12. Fujikawa-Yамамото, K. A method of the cell cycle analysis by a microcomputer. $J$. Kanazawa Med. Univ. 9, 105-112, 1984

13. Fujikawa-Yamamoto, K., E. Murakami and S. Odashima. An improved method of cell cycle analysis by a microcomputer and the examination utilizing anti-BrdU monoclonal antibody. J. Kanazawa Med. Univ. 10, 12-17, 1985

14. Gratzner, H.G. Monoclonal antibody to 5-bromo- and 5-iodo-deoxyuridine: A new reagent for the detection of DNA replication. Science 218, 474-475, 1982

15. Gray, J.W., J.H. Carver, Y.S. George and M.L. Mendelsohn. Rapid cell cycle analysis by measurement of the radioactivity per cell in a narrow window in S-phase $\left(\mathrm{RCS}_{\mathrm{i}}\right)$. Cell Tissue Kinet. 10, 97-109, 1977

16. Gray, J.W., P.N. Dean and M.L. Mendelsohn. Quantitative cell cycle analysis., In Flow Cytometry and Sorting. eds. M.R. Melamed, P.F. Mullaney and M.L. Mendelsohn. John Wiley and Sons, Inc., New York, pp. 383-407, 1979.

17. LATT, S.A. Fluorometric detection of deoxyribonucleic acid synthesis; possibilities for interfacing bromodeoxyuridine dye techniques with flow fluorometry. J. Histochem. Cytochem. 25, 913-926, 1977

18. LATt, S.A., Y.S. George and J.W. GraY. Flow cytometric analysis of bromodeoxyuridinesubstituted cells stained with 33258 Hoechst. J. Histochem. Cytochem. 25, 927-934, 1977

19. Lindmo, T. and E. AARENS. Selection of optimal model for the DNA histogram by analysis of error of estimated parameters. J. Histochem. Cytochem. 27, 297-304, 1979

20. Melamed, M.R. and P.F. Mullaney. An historical review of the development of flow cytometers and sorters., In Flow Cytometry and Sorting, eds. M.R. Melamed, P.F. Mullaney, and M.L. Mendelsohn, John Wiley and Sons, Inc., New York, p. 3-11, 1979.

21. OKada, S. A simple graphic method of computing the parameters of the life cycle of cultured mammalian cells in the exponential growth phase. J. Cell Biol. 34, 915-916, 1965

22. Puck, T.T. and J. Steffen. Life cycle analysis of mammalian cells I. Method for localizing metabolic events within the life cycle, and its application to the action of colcemid and sublethal doses of x-irradiation. Biophys. J. 3, 379-397, 1963

23. Robins, E. and M.D. ScharfF. The absence of a detectable $G_{1}$ phase in a cultured strain of Chinese hamster lung cells. J. Cell Biol. 34, 684-688, 1967

24. Siragi, S. and S.A. Bruce. Suppression of malignancy and differentiation in melanotic melanoma cells. Proc. Natl. Acad. Sci. 66, 72-78, 1970

25. Stanners, C.P. and J.E. Till. DNA synthesis in individual L-strain mouse cells. Biochim. Biophys. Acta 37, 406-419, 1960

26. TAKAHASHI, M. A multichannel method for the analysis of DNA content distribution using flow cytometric data. Comput. Biomed. Res. 14, 506-517, 1977

27. Watanabe, I. and S. OKadA. Effects of temperature on growth rate of cultured mammalian cells (L5178Y). J. Cell Biol. 32, 309-323, 1967

28. Zetterberg, A. and D. Killander. Quantitative cytochemical studies on interphase growth II. Derivation of synthesis curves from the distribution of DNA, RNA and mass values of 


\section{4}

individual mouse fibroblasts in vitro. Exp. Cell Res. 39, 22-32, 1965

29. ZieTZ, S. and C. Nicolini. Flow microfluorimetry and cell kinetics., In Biomathematics and

Cell Kinetics eds. A.J. Valleron and P.D.M. MacDonald. Elsevier/North-Holland Biomedical Press Amsterdam, pp. 357-395, 1978

(Received for publication, March 6, 1986) 